\title{
鉛プラグ入り積層ゴム支承の減衰材分散配置による熱力学特性の改善効果 IMPROVED THERMO-DYNAMIC BEHAVIOR OF LEAD-RUBBER ISOLATION BEARINGS DUE TO DISTRIBUTED LEAD-CORE CONFIGURATIONS
}

\author{
和 氣 知 貴 ${ }^{* 1}$, 石 井 建*2, 菊地 優*3 \\ Tomotaka WAKE, Ken ISHII and Masaru KIKUCHI
}

\begin{abstract}
To clarify the effectiveness of the distributed lead-core configurations of LRB, real-scale dynamic loading experiments and heatmechanics interaction analysis were carried out. Experiments and analyses revealed that the energy absorption performance tends to decline as the diameter of the lead core becomes larger, and that the multi-core LRB effectively restrains such decline in performance. In order to analyze a multi-core LRB, it is necessary to use a three-dimensional model, but this study reveals that analysis by CFS or FDM with a two-dimensional model is sufficiently accurate and is more conveniently.
\end{abstract}

Keywords : Lead-rubber isolation bearings, Multi-core, Real-scale dynamic and cyclic loading test,

Heat-mechanics interaction behavior analysis, Three-dimensional heat conduction analysis, Constant Flux Solution 鉛プラグ入り積層ゴム，マルチプラグ，実大動的繰返し加力実験，熱力学連成挙動解析，三次元熱伝導解析，定熱流束解析

\section{1. 序論}

鉛プラグ入り積層ゴム支承（以下 LRB）は減衰材である鉛プラグ を複数本に分散配置することによって，鉛プラグの総せん断面積を 変えずに, 鉛プラグの表面積を大きくすることが可能である. 言い換 えると, 鉛プラグのせん断抵抗力を変えずに, 鉛プラグから周囲への 放熱特性を改善することができる．LRB は平面形状が四角と丸の型 があり，角型 LRB は一部の鉛径が小さい場合を除いて鉛プラグが 4 本に分散配置されており, 丸型 LRB は鉛プラグ 1 本の構成となって いる. 以下本論では, 鉛プラグが分散配置された支承をマルチプラグ LRB と呼び，鉛プラグが 1 本の支承をシングルプラグ LRB と呼ぶ こととする。

LRB は長周期，長時間地震動などにより大きな変形を繰り返し受 けると, 鉛プラグが発熱し, エネルギー吸収性能が低下することが確 認されている.この現象を予測する方法として, 鉛プラグ温度と LRB の降伏応力度の関係式を用いた熱・力学連成挙動解析が有効である ことが示されている. 鉛プラグ温度と LRB の降伏応力度の関係は, LRB のエネルギー吸収性能評価に大きな影響を与える重要な関係で あり，計測技術の進歩とともにこれまでにいくつかの関係式 1), 2), 3, 4) が提案されている. 著者らもまた, 実験結果に基づき, ひずみ速度依 存性を考慮した，鈶プラグ温度が- $25^{\circ} \mathrm{C}$ から $300^{\circ} \mathrm{C}$ までの広範囲に おける LRB の降伏応力度の関係式を提案している5).

鉛プラグの発熱と積層ゴム体への熱伝導を考慮する手法について は丸型 LRB に対して差分法 1)を用いる方法（FDM 解法）と，定熱流 束解析手法 2),6)を用いる方法 (CFS 解法) とが提案されている. FDM
解法は, 複雑な形状の LRB に対しても実現象に近い評価が得られる が, 解析対象に合わせて詳細なモデルを作成する必要がある. 一方, CFS 解法は熱伝導モデルを単純化することで，より簡易に FDM 解 法と同等の評価が得られるが, 角型 LRB のような複雑な形状につい ての適用性は検討されていない.

鉛プラグの分散配置による改善効果に関する既往の研究では，マ ルチプラグ LRB とシングルプラグ LRB に対して実施された, 長周 期長時間地震動を想定した実大動的実験 7)から，設計上の降伏荷重 特性を変えずに，エネルギー吸収に伴う鉛プラグの温度上昇量が抑 えられ，累積エネルギー吸収量が増大寸ることが河内山らにより実 験的に示されている. 近藤らは, シングルプラグ LRB と, 実験のた め特別に鉛プラグを 3 本に分散配置した丸型のマルチプラグ LRBに 対して熱伝導を考慮した熱・力学連成解析 8)を行い, 縮小試験体によ る動的繰返し加力実験で得られたエネルギー吸収量の違いを FDM 解法により解析的に表現できることを示している。これまでの研究 により，鉛プラグの分散配置による理解が進んできたが，実大の積 層ゴムにおける改善効果についての定量的な評価はなされていなく 以下については十分に把握されていない.

1）LRB の鉛プラグの分散配置，鉛プラグ径，およびゴム層総厚さ による形状の違いがエネルギー吸収性能に与える影響

2）実大マルチプラグ LRB に対する熱力学連成挙動解析の適用性 本研究では，上記 1）に関して，鉛プラグ径，およびゴム層総厚さ を変化させた実大サイズのマルチプラグ LRB, シングルプラグ LRB に対して動的繰返し加力実験を行い, エネルギー吸収性能と形状の
*1 オイレス工業(株)免制震事業部開発部 修士(工学)

*2 北海道大学大学院工学研究院 助教. 博士 (工学)

*3 北海道大学大学院工学研究院 教授 $\cdot$ 博士 (工学)
Development Dept., Damping and Isolation Division, Oiles Corporation, M.Eng. Assist. Prof., Faculty of Engineering, Hokkaido University, Dr.Eng.

Prof., Faculty of Engineering, Hokkaido University, Dr.Eng. 
関係を確認する．また，上記 2) に関して，実験と解析の両面から熱 力学連成挙動解析手法のマルチプラグ LRBへの適用方法について示 す. さらに, 著者らの提案する LRB 降伏荷重評価式のマルチプラグ LRB への適用性について検証し, 鉛プラグの分散配置がエネルギー 吸収性能に与える影響を定量的に評価する手法を提案する.

\section{2. 実験計画}

鉛プラグの分散配置によるエネルギー吸収性能の改善効果を確認 するため, 実大サイズのマルチプラグ LRB, シングルプラグ LRB に 対して動的繰り返し加力実験を行う.

\section{1 試験体}

試験体は鉛プラグ径, 二次形状係数（積層ゴム外形寸法とゴム層総 厚さの比)を変化させた図 1 , 表 1 に示寸形状のマルチプラグ LRB, シングルプラグ LRB である. 試験体 $\mathrm{S} 1$ と $\mathrm{R} 1, \mathrm{~S} 2$ と R2, $\mathrm{S} 3$ と R3, $\mathrm{S} 4$ と R4 は，それぞれ設計上の基本特性がほぼ同じになるように試 験体外形寸法, 鉛プラグ径を設定しており，鉛プラグ径，および分散 配置による影響を確認寸るための試験体である. 試験体 S4，R4 は，
試験体 S3, R3 と同じ平面形状だが，ゴム層総厚さを $200 \mathrm{~mm}$ とし ており, 二次形状係数が異なる試験体である. 試験体 S5 は通常の製 品では無い極めて太い鉛プラグ径を有しているが，鉛プラグ径によ る性能変化を確認することを目的として設定した試験体である．試 験体 S6 は試験体 S3 を 4 分割したものと同形状としており, マルチ プラグ LRB のの CFS 解法適用を検討寸るための試験体である．試 験体内部温度を確認するため, 図 1 に黒丸（・）で示寸位置に熱電 対を設置した．マルチプラグ LRB では鉛プラグ中心部（Ch.1）と鉛 プラグ間中心のゴム部（Ch.2），シングルプラグ LRB では鉛プラグ 中心部（Ch.1）に熱電対を設置した。試験体 S6 については, 鉛プラ グ中心部（Ch.1）の他，マルチプラグ LRB の鉛プラグ間中心の内部 ゴム部を想定したゴム層の端部 $(\mathrm{Ch} .2)$, および鉛プラグ間中心の内 部鋼板温度を想定した内部鋼板の端部 (Ch.3) に熱電対を設置した.

\section{2 試験機}

実験は動的に繰り返し加力が可能であり, 加力テーブルの摩擦を 含まない水平力の計測が可能な二軸ロードセルを有する $3 \mathrm{MN}$ 二軸 試験機 7)を用いて実施した。
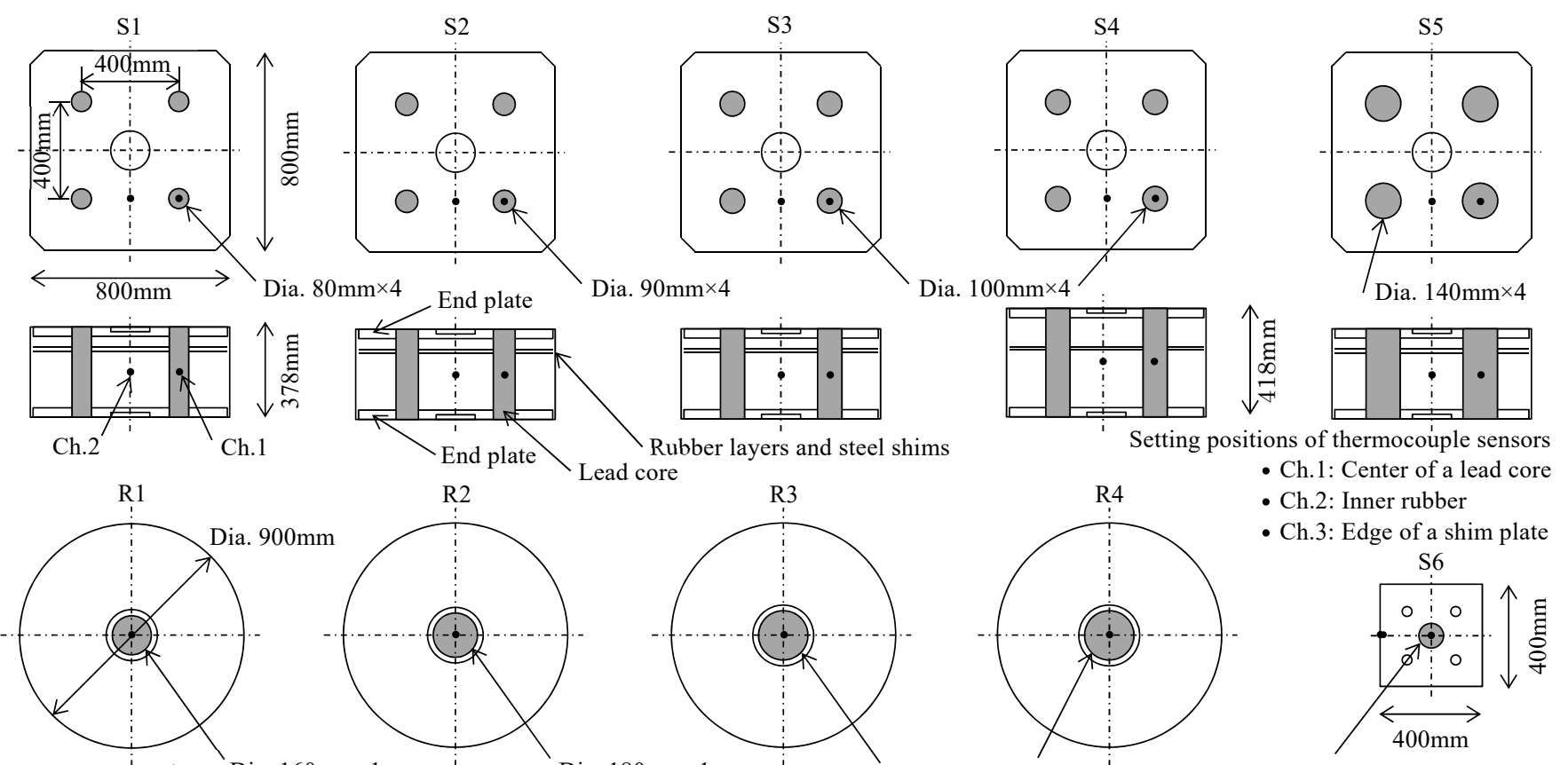

Ch. 1 Dia. $160 \mathrm{~mm} \times 1$

Dia. $180 \mathrm{~mm} \times 1$

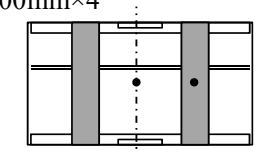

Setting positions of thermocouple sensor

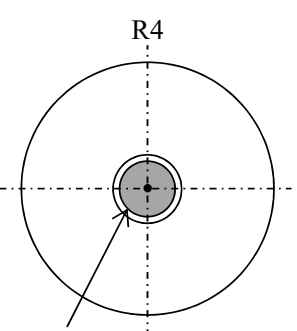

- Ch.1: Center of a lead core

- Ch.2: Inner rubber

- Ch.3: Edge of a shim plate

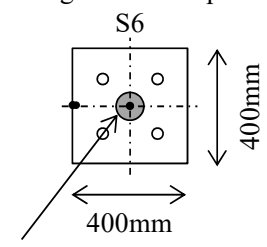

Dia. $100 \mathrm{~mm} \times 1$
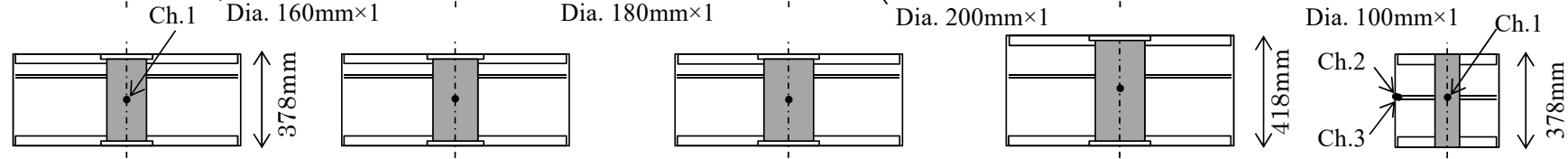

Fig.1 Tested actual-size lead-rubber isolation bearings. (Black makers indicate the positions of thermocouple sensors.)

Table 1 Basic geometrical parameters of lead-rubber isolation bearings.

\begin{tabular}{|c|c|c|c|c|c|c|c|c|c|c|c|}
\hline Parameters & Unit & S1 & $\mathrm{S} 2$ & S3 & $\mathrm{S} 4$ & S5 & S6 & $\mathrm{R} 1$ & $\mathrm{R} 2$ & R3 & $\mathrm{R} 4$ \\
\hline Rubber shape & $\mathrm{mm}$ & $\begin{array}{l}\text { Square } \\
800\end{array}$ & $\begin{array}{c}\text { Square } \\
800\end{array}$ & $\begin{array}{c}\text { Square } \\
800\end{array}$ & $\begin{array}{c}\text { Square } \\
800\end{array}$ & $\begin{array}{l}\text { Square } \\
800\end{array}$ & $\begin{array}{l}\text { Square } \\
400\end{array}$ & $\begin{array}{l}\text { Round } \\
900\end{array}$ & $\begin{array}{l}\text { Round } \\
900\end{array}$ & $\begin{array}{l}\text { Round } \\
900\end{array}$ & $\begin{array}{c}\text { Round } \\
900\end{array}$ \\
\hline Rubber shear modulus & $\mathrm{N} / \mathrm{mm}^{2}$ & 0.392 & 0.392 & 0.392 & 0.392 & 0.392 & 0.392 & 0.392 & 0.392 & 0.392 & 0.392 \\
\hline Rubber thickness $\times$ layers & $\mathrm{mm}$ & $5.0 \times 32$ & $5.0 \times 32$ & $5.0 \times 32$ & $5.0 \times 40$ & $5.0 \times 32$ & $5.0 \times 32$ & $5.0 \times 32$ & $5.0 \times 32$ & $5.0 \times 32$ & $5.0 \times 40$ \\
\hline Shim plate thickness $\times$ plates & $\mathrm{mm}$ & $4.3 \times 31$ & $4.3 \times 31$ & $4.3 \times 31$ & $4.3 \times 39$ & $4.3 \times 31$ & $4.3 \times 31$ & $4.3 \times 31$ & $4.3 \times 31$ & $4.3 \times 31$ & $4.3 \times 39$ \\
\hline End plate thickness $\times$ plates & $\mathrm{mm}$ & $40 \times 2$ & $40 \times 2$ & $40 \times 2$ & $40 \times 2$ & $40 \times 2$ & $40 \times 2$ & $40 \times 2$ & $40 \times 2$ & $40 \times 2$ & $40 \times 2$ \\
\hline Lead co & $\mathrm{mm}$ & 80 & 90 & 100 & 100 & 140 & 100 & 160 & 180 & 200 & 200 \\
\hline Number of lead core & - & 4 & 4 & 4 & 4 & 4 & 1 & 1 & 1 & 1 & 1 \\
\hline Design value of yielding force & $\mathrm{kN}$ & 160.3 & 202.9 & 250.4 & 250.4 & 490.9 & 62.6 & 160.3 & 202.9 & 250.4 & 250.4 \\
\hline Aspect ratio (S2) & - & 5.0 & 5.0 & 5.0 & 4.0 & 5.0 & 2.5 & 5.6 & 5.6 & 5.6 & 4.5 \\
\hline
\end{tabular}




\section{3 実験条件}

実験は表 2 に示す条件とし，せん断ひずみは $100 \%, 200 \%$ の 2 水 準とし正弦波による加力を行った。加力速度は出荷検查時の加力速 度に相当する約 $15 \mathrm{~mm} / \mathrm{s}$ と周期 $8 \mathrm{~s}, 4 \mathrm{~s} ， 2 \mathrm{~s}$ の 4 水準，圧縮面圧は試 験機能力の制約から $5 \mathrm{MPa}$ とした。繰り返し回数は $15 \mathrm{~mm} / \mathrm{s}$ と周期 $8 \mathrm{~s}$ の条件では繰り返し加力による鉛プラグ温度上昇が見込めないこ とから 4 サイクルとした。周期 $4 \mathrm{~s}$ の条件は累積変形距離が $50 \mathrm{~m}$ を 超えるように, 周期 $2 \mathrm{~s}$ の条件は試験機能力により回数を設定した. ゴム層総厚さが $200 \mathrm{~mm}$ の試験体 $\mathrm{S} 4, \mathrm{R} 4$ は括弧内に示寸条件とした.

\section{3. 形状の違いがエネルギー吸収性能に与える影響}

鉛プラグ本数, 鉛プラグ径, ゴム層総厚さを変えた試験体形状の違 いによる履歴特性, エネルギー吸収性能, 鉛プラグ温度上昇量の違い を確認する. 本章では地震時の挙動を想定したせん断ひずみ $200 \%$, 周期 $4 \mathrm{~s} ， 40$ サイクルの動的繰り返し実験結果について示す.

\section{1 鉛プラグ分散配置による影響}

試験体 S3, R3 の水平力-水平変位関係，および加力サイクルごと のエネルギー吸収量の推移, 鉛プラグ中心部の温度変化を図 2 に示 す. マルチプラグ LRB, シングルプラグ LRB ともに加力初期の水平 力-水平変位関係はほぼ同じ形状を示した. 加力回数の増加とともに 両者とも最大水平力の低下がみられるが，マルチプラグ LRB はシン グルプラグ LRB に比べて最大水平力の低下が少なく, 最終サイクル における履歴面積が大きくなっている，加力サイクルごとのエネル ギー吸収量の変化は, 加力開始から 5 サイクル程度までは両者とも に同程度だが，それ以降のサイクルでは，マルチプラグ LRB はシン グルプラグ LRB に比べてエネルギー吸収量の低下が小さい. 鉛プラ グ中心温度は加力開始直後から差が見られ，マルチプラグ LRBにお ける加力終了時における温度上昇量はシングルプラグ LRBに比べて $70^{\circ} \mathrm{C}$ 程度低い結果となった。

\section{2 鉛プラグ径による影響}

ゴム層総厚さが $160 \mathrm{~mm}$ である試験体 $\mathrm{S} 1 \sim \mathrm{S} 3, \mathrm{~S} 5, \mathrm{R} 1 \sim \mathrm{R} 3$ に対し て実施した動的繰り返し加力実験結果について, 3 サイクル目の降伏 応力度を基準とした加力回数 5, 10, 20,39.5 サイクル目の変化率と 鉛プラグ径との関係を図 3 に示す. 鉛プラグ径 $80 \mathrm{~mm}$ 140mm はマ ルチプラグ LRB の結果で, 鉛プラグ径 160 200 mm はシングルプラ グ LRB の結果であり, 試験体の鉛プラグ総せん断面積は試験体 $\mathrm{S} 1$ と R1，S2 と R2, S3 と R3 で同じである. 降伏応力度は加力回数が 増えるほど低下し, その低下率は試験体の鉛プラグ総せん断面積で はなく, 鉛プラグ径と非常によい相関を示し, 鉛プラグ本数によらず 鉛径が太くなるほど大きくなった。マルチプラグ LRB は試験体の鉛 プラグ総せん断面積を変えずに鉛プラグ径を小さくすることができ るため，鉛プラグの分散配置がエネルギー吸収量の低下を抑制する 効果があることがよくわかる. 最終サイクルにおける低下率は, マル チプラグ LRB は同じ鉛プラグ総せん断面積を有するシングルプラグ LRB に比べて $17 \%$ 程度の改善が確認された.

\section{3 二次形状係数による影響}

試験体 $\mathrm{S} 3, \mathrm{R} 3$ と同じ平面形状で二次形状係数が異なる試験体 S4, R4 の動的繰り返し加力実験結果を図 4 に示す. 試験体 S4, R4 はゴ ム層総厚さが試験体 S3, R3 に比べて厚いためせん断変形量が大きく なり, 試験体 S3, R3 と比べると加力サイクル当たりのエネルギー吸
Table 2 Dynamic test conditions in 3MN testing apparatus.

\begin{tabular}{|c|c|c|c|c|}
\hline Pressure & Shear strain $\gamma$ & $\begin{array}{c}\text { Period T } \\
\text { (Sin } \\
\text { wave) }\end{array}$ & $\begin{array}{l}\text { Number } \\
\text { of cycles }\end{array}$ & $\begin{array}{c}\text { Cumulative } \\
\text { travel } \\
\text { distance }\end{array}$ \\
\hline $\mathrm{N} / \mathrm{mm}^{2}$ & $\%$ & $\mathrm{~s}$ & Cycles & $\mathrm{m}$ \\
\hline \multirow{8}{*}{5} & \multirow{4}{*}{100} & 66.7 & 4 & $2.6(3.2)$ \\
\hline & & 8 & 4 & $2.6(3.2)$ \\
\hline & & 4 & 80 & $51.2(64)$ \\
\hline & & 2 & 60 & $38.4(48)$ \\
\hline & \multirow{4}{*}{200} & 125 & 4 & $5.1(6.4)$ \\
\hline & & 8 & 4 & $5.1(6.4)$ \\
\hline & & 4 & 40 & $51.2(64)$ \\
\hline & & 2 & $20(16)$ & $25.6(25.6)$ \\
\hline
\end{tabular}

Conditions of $\mathrm{S} 4, \mathrm{R} 4$ specimens are described in parentheses.
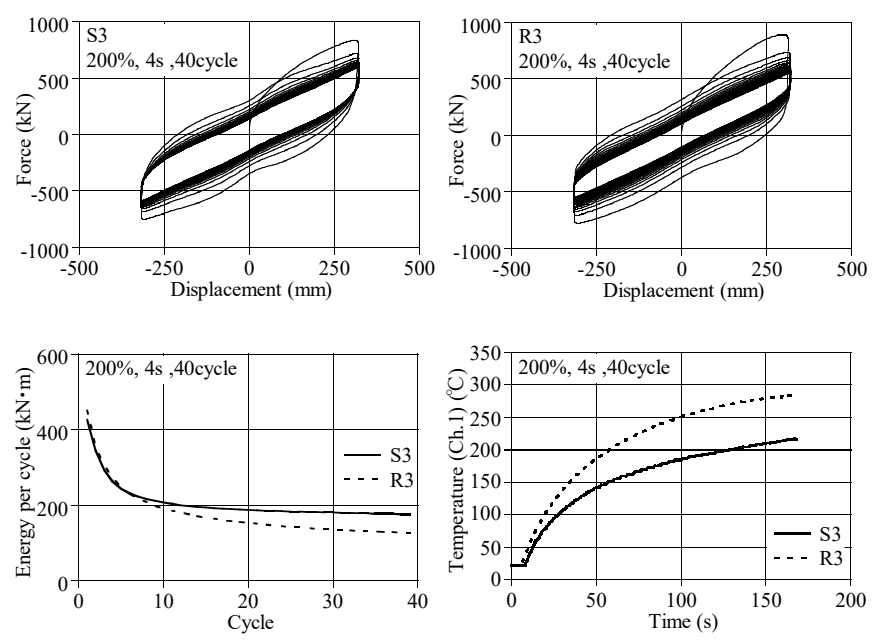

Fig.2 Comparison of experimental results of specimens S3 and R3.

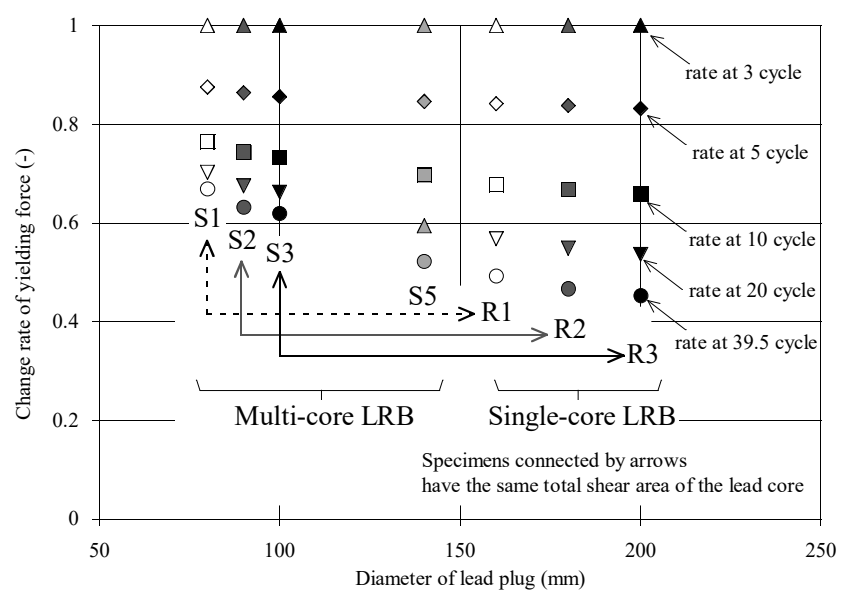

Fig.3 Relationship between yielding force degradation rate and lead core diameter obtained from experiments.

収量は大きくなるが，鉛プラグ単位体積あたりのエネルギー吸収量 の変化はほぼ一致した．鉛プラグ中心温度の変化は，シングルプラ グ LRB では $300^{\circ} \mathrm{C}$ 近くまで上昇したが，マルチプラグ LRB では $200^{\circ} \mathrm{C}$ 程度に留まった.この結果は図 4 に合わせて示した試験体 $\mathrm{S} 3$, R3 の鈶プラグ中心部の温度変化とほぼ同じである. 二次形状係数に よるエネルギー吸収性能の違いを確認するため, 図 5 に降伏応力度 
の 3 サイクル目からの変化率を加力回数ごとに示寸.マルチプラグ LRB 同士, シングルプラグ LRB 同士で比べると, 二次形状係数が変 わっても降伏応力度の低下率に顕著な違いは見られなかった。
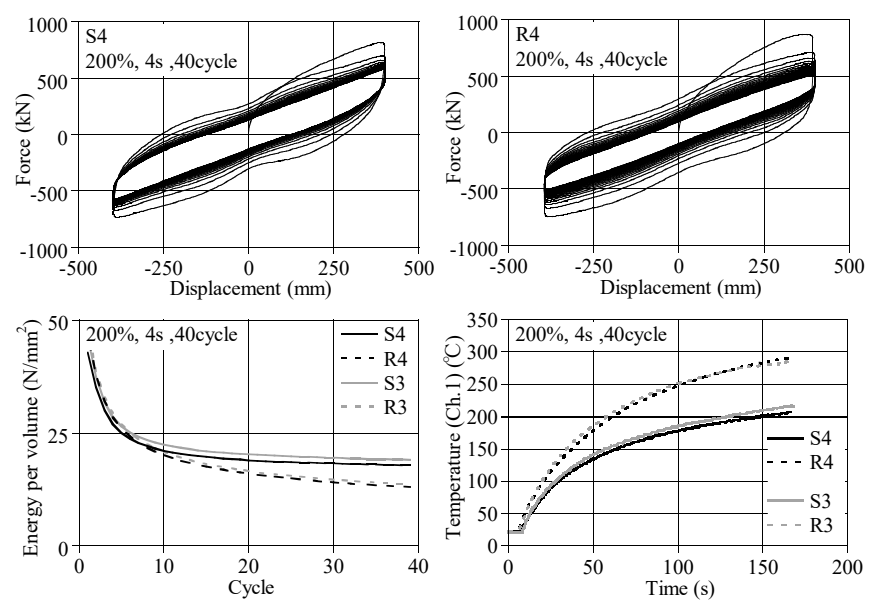

Fig.4 Comparison of experimental results of specimens S4 and R4.

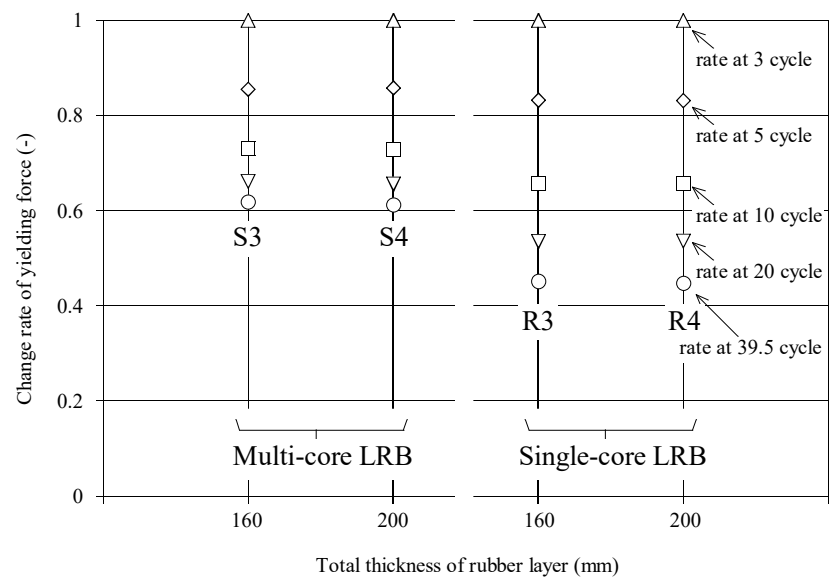

Fig. 5 Relationship between yielding force degradation rate and total thickness of rubber layer obtained from experiments.

\section{4.熱力学連成挙動解析における鉛プラグからの放熱の考慮方法}

LRB が繰り返し加力を受けるとエネルギー吸収に伴い鉛プラグが 発熱し, 鉛プラグのエネルギー吸収性能が低下する. 鉛プラグに生じ た熱は時間の経過とともに積層ゴム体へ移動するため, 繰り返し加 力によるエネルギー吸収性能の変化を解析的に表現するためには, エネルギー吸収による鉛プラグの温度上昇とそれに伴うエネルギー 吸収性能の低下，および鉛プラグから積層ゴム体への放熱を考慮し た熱力学連成挙動解析が必要となる．本章では鉛プラグから積層ゴ ム体への放熱を考慮する方法として提案されている，差分法（FDM 解法）と定熱流束解析手法（CFS 解法）について説明し，マルチフ ラグ LRBへの適用性について検討する.

\subsection{FDM 解法のマルチプラグ LRB への適用}

FDM 解法により鉛プラグからの熱の移動を考慮する際，外形が丸 型のシングルプラグ LRB の場合, 鉛プラグが中心に配置されている ため，二次元軸対称モデルを適用できる．一方，マルチプラグ LRB は外形が角型であるため三次元モデルとする必要がある．積層ゴム 体の形状を三次元モデルで表現することにより複雑な形状のマルチ プラグ LRB の解析を精度よく行うことができる. 図 6 にマルチプラ

グ LRB の三次元熱伝導解析モデルの概念図を示す. 対称性を考慮し 高さ方向に半分, 平面形状の中心角を 45 度で切り取った範囲で熱伝 導解析モデルを作成し, 要素としてフランジプレート, 連結鋼板, ゴ ム層，内部鋼板をそれぞれモデル化した．FDM解法では，解析ステ ップごとに隣接する要素間の熱伝導方程式を全要素にわたり解くこ とによりモデル各部の温度が算出される.

\section{$4.2 \mathrm{CFS}$ 解法のマルチプラグ LRB への適用}

CFS 解法は，加力中における鉛プラグ温度を簡易に計算するため の手法であり，積層ゴム体のモデル，鉛プラグからの熱の移動を単 純化し，鉛プラグからの放熱について図 7 に示すように二通りの経 路を仮定する. 経路 (a) は, 鉛プラグ上下端から鋼板への経路であり, 単位時間あたりの放熱量は，半無限に広がる鋼材の表面に円形の熱 源が接触している状態を仮定して計算する．経路(b)は，鉛プラグ側 面から内部鋼板への経路であり，単位時間あたりの放熱量は，無限 の直径を有する中空鋼管の内径部に熱源が接触している状態を仮定 して計算している．放熱経路を上記のように仮定することで，鋼材 内の熱拡散方程式を理論モデルに合致するように，一つの熱伝導方 程式が得られ，これを解くことにより鉛プラグ温度が算出される.

シングルプラグ LRB は上記の仮定に基づき鉛プラグ温度を算出で きる. マルチプラグ LRB に対しては鉛プラグ間の熱的相互作用が十 分に小さいと仮定し，分散配置されたそれぞれの鉛プラグに対して CFS 解法を適用することで, 鉛プラグ温度を算出することができる. マルチプラグ LRB の場合, 半無限に広がる鋼材に熱源が接触して いるという仮定は隣接する鉛プラグによる影響を無視したものとな っており，適用するには鉛プラグ間の熱的相互作用が十分に小さい

(a)

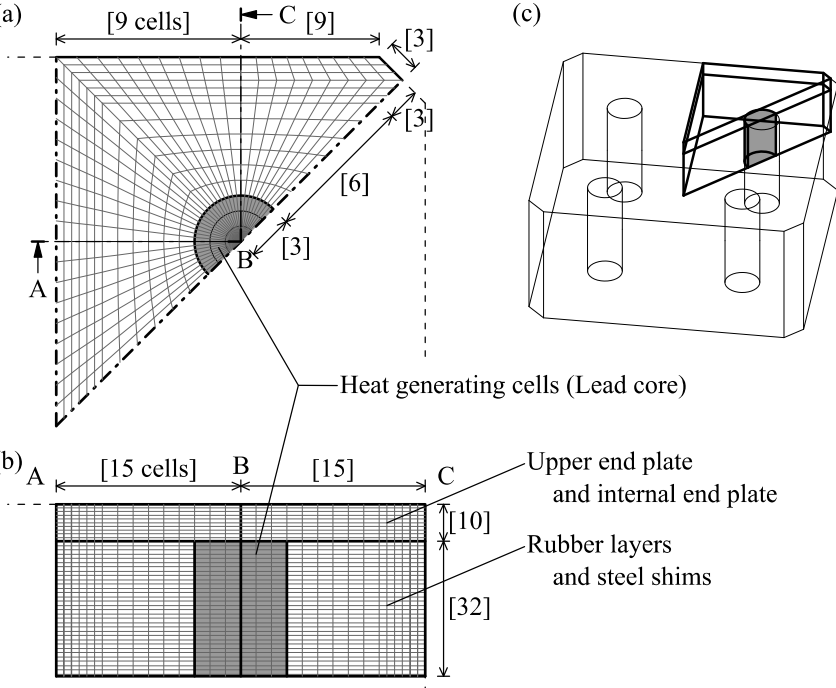

Fig.6 Outline drawing of three-dimensional heat conduction model (a) plan (b)cross section (c) projection

(a)

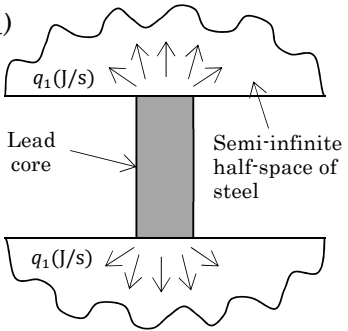

(b)

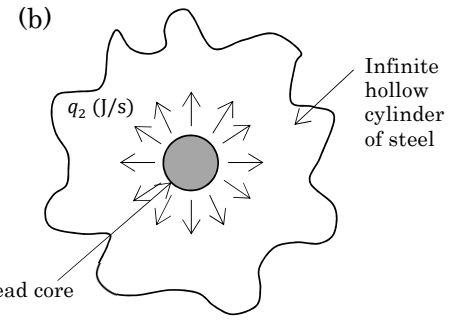

(b)

Fig.7 Conceptual diagram of Constant Flux Solution. 
ことを確認する必要がある．マルチプラグ LRB に対して CFS 解法 が適用できると, 三次元モデルを用意する必要がなくなり, 計算量も 少なくなり大幅な効率化を図ることができる. マルチプラグ LRBに おける鉛プラグ間の熱的相互作用ついては 5 章で説明する.

\section{3 熱力学連成挙動解析手法}

LRB の熱力学連成挙動解析手法について説明する. 解析を行うに はLRB 降伏荷重と試験体温度の関係が必要であり, 本論では著者ら の提案する参考文献 5 に示されている式(1) (3)を用いた.

$\mathrm{Q}_{L R B}=\mathrm{Q}_{\text {Lead }}+\mathrm{Q}_{R B}=\tau_{P b} \cdot A_{P b}+\tau_{R B} \cdot A_{R B}$

$\tau_{R B}\left(T_{R B S}, \gamma, V_{\gamma}\right)=1.1853 \cdot f_{R B}\left(T_{R B S}\right) \cdot\left(2.8+7.4 \gamma+2.7 V_{\gamma}^{0.5}\right) \cdot 10^{-3}$

$$
f_{R B}\left(T_{R B S}\right)=1.405 \cdot \exp \left(-0.05 \cdot V_{\gamma}^{0.07} \cdot T_{R B S}\right)
$$$$
\left(-30 \leq T_{R B S}<0\right)
$$

$$
f_{R B}\left(T_{R B S}\right)=\exp \left(-0.017 \cdot\left(T_{R B S}-20\right)\right)
$$

$$
\left(0 \leq T_{R B S} \leq 40\right)
$$

$\tau_{P b}\left(T_{P b}, V_{\gamma}\right)=3.5+10.69 V_{\gamma}^{0.156} \cdot \exp \left\{-0.0148 V_{\gamma}^{-0.08} \cdot T_{P b}\right\}$

式(1) (3)において, $\mathrm{Q}_{L R B}(\mathrm{~N})$ は LRB 降伏荷重, $\mathrm{Q}_{\text {Lead }}(\mathrm{N})$ は鉛プラ グ降伏荷重, $\mathrm{Q}_{R B}(\mathrm{~N})$ は $\mathrm{RB}$ 切片荷重, $\tau_{P b}\left(\mathrm{~N} / \mathrm{mm}^{2}\right)$ は鉛プラグ降伏 応力度, $A_{P b}\left(\mathrm{~mm}^{2}\right)$ は鉛プラグせん断面積, $\tau_{R B}\left(\mathrm{~N} / \mathrm{mm}^{2}\right)$ は $\mathrm{RB}$ せん 断応力度, $A_{R B}\left(\mathrm{~mm}^{2}\right)$ は $\mathrm{RB}$ せん断面積である. $f_{R B}\left(T_{R B S}\right)$ は試験体初 期温度 $T_{R B S}$ による $\mathrm{RB}$ せん断応力度の依存性を表す係数であり, $T_{P b}$ $\left({ }^{\circ} \mathrm{C}\right)$ は鉛プラグ温度, $\gamma(-)$ は積層ゴムせん断ひずみ, $V_{\gamma}(-/ \mathrm{s})$ はせん断 ひずみ速度である．鉛プラグ降伏応力度は式(3)から鉛プラグ温度と せん断ひずみ速度から計算することができ図 8 に示す関係となる. 本式では，LRB の降伏荷重を鉛プラグ降伏荷重と RB 切片荷重に分 離しているため，鉛プラグ径だけでなくゴムせん断面積の変化につ いても考慮することが可能である. 図 9 に熱力学連成挙動解析の解 析フローを示す.まず，(a) 式(3)を用いて鉛プラグ温度とせん断ひず み速度から，そのステップの鉛プラグ降伏応力度を計算し，(b) LRB 降伏荷重を式(1), (2)を用いて計算する. (c) 変位増分と荷重増分より 計算される履歴吸収エネルギーから，式(2)を用いて算出されるゴム によるエネルギー吸収量を差し引き, 鉛プラグが吸収したエネルギ 一を算出する。（d）CFS 解法，FDM 解法のどちらかを用いて鉛プラ グ温度を算出し, 次の解析ステップ(a)に進む.

\section{5. 鉛プラグ間の熱的相互作用の確認実験}

繰り返し加力に伴う降伏応力度の低下は, 図 3 の結果から試験体 の鉛プラグ総せん断面積ではなく，分割された鉛プラグ 1 本の直径 と高い相関があることが確認された。これは，マルチプラグ LRBに おいて, 繰り返し加力中に鉛プラグ間の熱的相互作用がほとんど生 じていないことを示唆している. 本章では, 実験から得られた繰り返 し加力時におけるマルチプラグ LRB の鉛プラグ間中央部の温度変化 と FDM 解法による解析結果から鉛プラグ間の熱的相互作用が十分 に小さいことを示す. また，マルチプラグ LRB を鉛プラグ本数で分 割した試験体に対して実験を行い，鉛プラグ間の熱的相互作用が十 分に小さいことを実験的に確認する.

\section{1 マルチプラグ LRB の鉛プラグ間の熱的相互作用}

試験体 S3 に対して実施したせん断ひずみ 200\%，周期 4s，40 サ イクル繰り返し加力実験から得られた水平力-水平変位関係を図 10 に，鉛プラグ中央部の温度変化(ch.1) と，鉛プラグ間中央に位置する ゴムの温度変化(ch.2)を図 11 に示す. なお, 図 10,11 には LRB の結

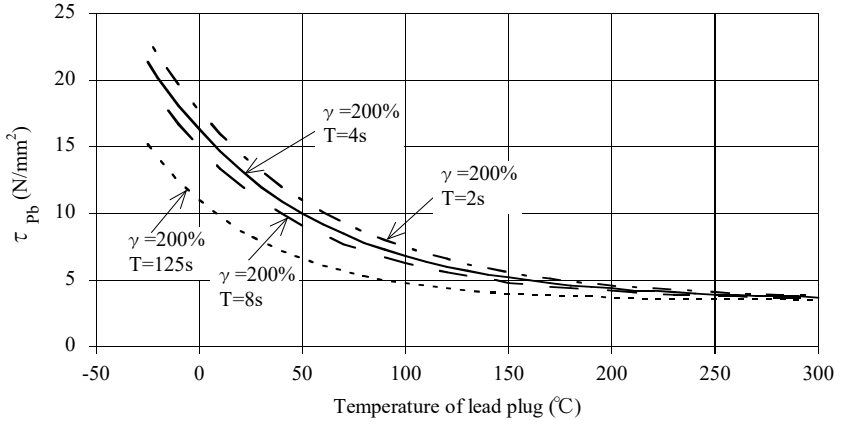

Fig.8 Relationship between yielding stress and temperature of lead core using for analysis.

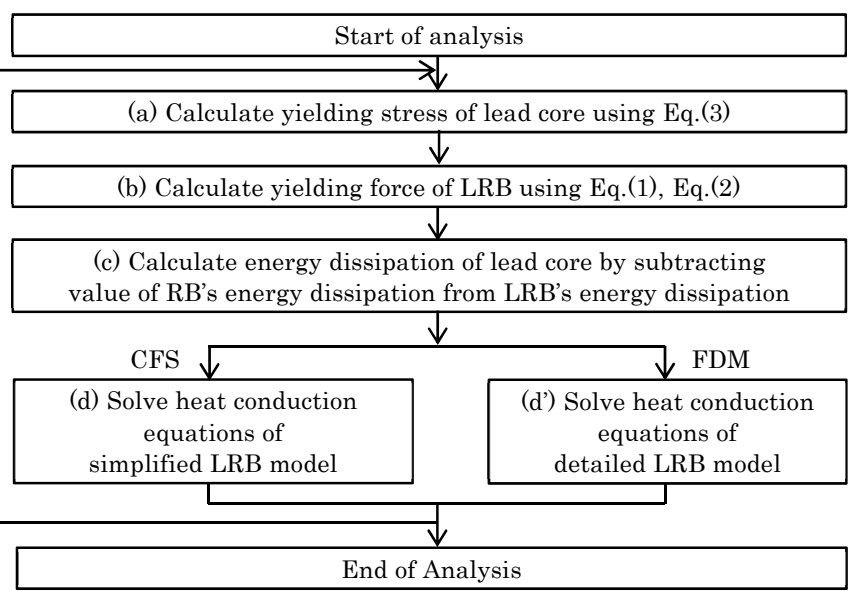

Fig.9 Flowchart of heat-mechanics interaction analysis.

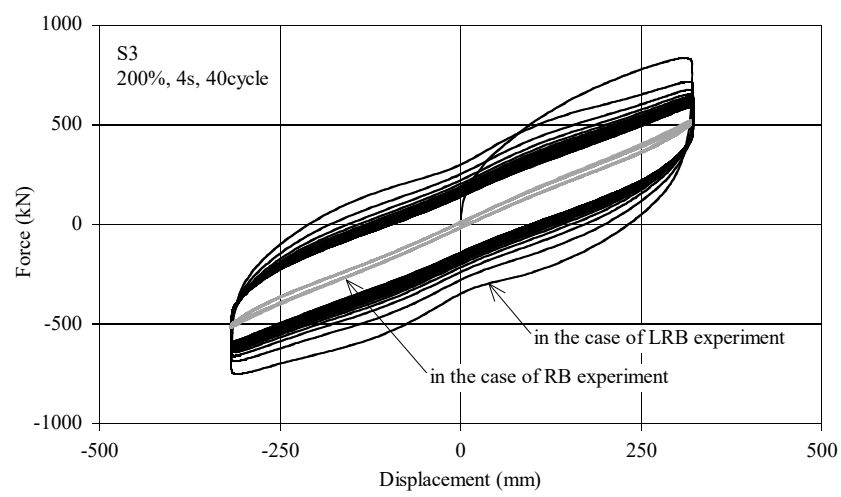

Fig.10 Force-displacement relationships of LRB and RB (S3).

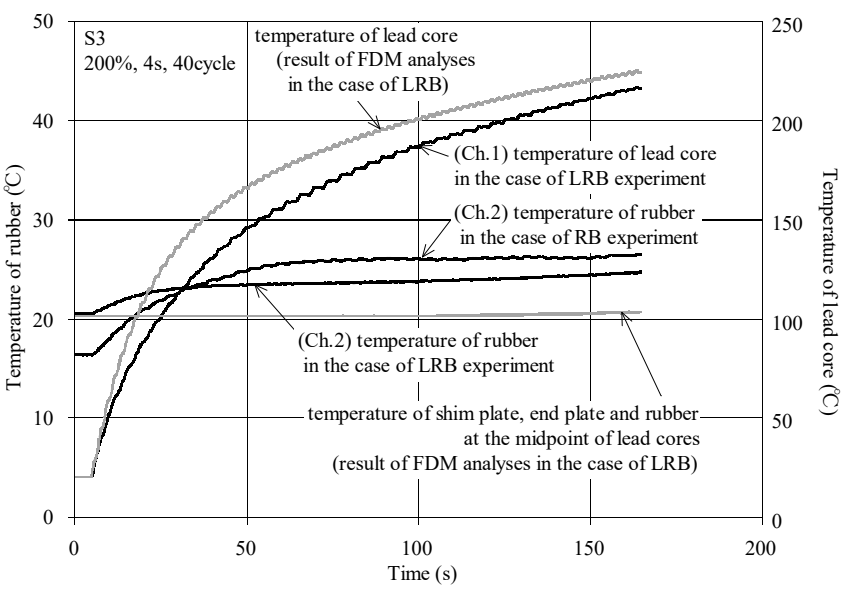

Fig.11 Experimental results and analysis results of temperature change inside specimen in RB and LRB (S3). 
果と, 鉛プラグ挿入前の RB における結果を合わせて示している.

$\mathrm{RB}$ は繰り返し加力を行っても履歴面積に大きな変化は見られず, 積 層ゴム内部のゴム温度上昇は $10^{\circ} \mathrm{C}$ 程度であった。 LRB は繰り返し 加力により履歴面積が減少し, 鉛プラグ温度が $216.6^{\circ} \mathrm{C}$ まで上昇し たが，鈆プラグ間中央部のゴム温度上昇量は $5^{\circ} \mathrm{C}$ 程度であった。 $\mathrm{RB}$ と LRB に対して実施した実験の結果, 鉛プラグ間中央部のゴム温度 に顕著な違いは見られなかった. RB の方が鉛プラグ間中央部のゴム 温度上昇量は $5{ }^{\circ} \mathrm{C}$ 程度大きい值を示したが，これは，鉛プラグ挿入前 の RB では LRB に比べて一次形状係数が小さくなるため, ゴムの非 線形性が大きくなることが要因として考えられる. 図 11 に FDM 解 析から得られた鉛プラグ間中央部のゴム温度，内部鋼板および連結 鋼板内部温度の変化を示す．鉛プラグ間中央部の温度上昇量は内部 ゴム, 内部鋼板, 連結鋼板内部ともに $0.5^{\circ} \mathrm{C}$ 以下であり, ほとんど上 昇しない結果となったＳ3 試験体による繰り返し加力実験と FDM による解析検討から, 鉛プラグ間中央部の温度上昇量は鉛プラグ中 心部の温度上昇量に比べて十分に小さいことが確認できる.

\section{2 分割試験体とマルチプラグ LRB との比較}

マルチプラグ LRB の鉛プラグ間の熱的相互作用をさらに詳しく確 認するために，図 12 に示すように試験体 $\mathrm{S} 3$ （LRB $5800 ） を 4$ 分割 したものと同形状の試験体 S6（LRB 4000 試験体）に対して実験を 行い, 両者の結果を比較する. 試験体 $\mathrm{S} 6$ の水平力の結果を 4 倍した ときに，試験体 S3 の結果と一致すれば，試験体 S3 における鉛プラ グ間の熱的相互作用が水平力にほとんど影響を与えていないと判断 できる. 一方, 試験体 S3 の結果の方が水平力の低下が大きければ, 鉛プラグ間で熱的相互作用が生じており，鉛プラグ温度の変化が隣 接する鉛プラグの影響を受けていることとなる.

試験体 S6 は試験体 S3 に対して二次形状係数が小さく座屈しやす い形状のため, 同じせん断変形量を与えた場合, 鉛直アクチュエータ 一の制御が荷重制御の状態では，鉛直方向の沈み込み量が大きくな りすぎ，試験体の変形状態が同じにならない，そのため，試験体 S6 の実験では, 試験体の変形状態を試験体 S3 と合わせるため, 鉛直ア クチュエーターの制御を変位制御とし, 試験体 S3 の実験で得られた 鉛直変位の時刻歴波形を用いて加力した.

図 13 に試験体 S6 に対して実施したせん断ひずみ $200 \%$, 周期 $4 \mathrm{~s}$, 40 サイクル繰り返し加力実験から得られた水平力-水平変位関係を 示寸. 図 13 には比較のため試験体 S3 の結果を縦軸を 4 倍にして示 している. 水平力-水平変位関係は試験体 $\mathrm{S} 6$ と $\mathrm{S} 3$ でほぼ同じ履歴形 状を示した．試験体 S6，S3 の内部温度変化を図 14 に示す．鉛プラ グの最大温度は試験体 $\mathrm{S} 6$ で $217.0^{\circ} \mathrm{C}$, 試験体 $\mathrm{S} 3$ で $216.6^{\circ} \mathrm{C}$ となり ほぼ同じ結果となった．また, 試験体 S6 における内部鋼板端部にお ける繰返し加力終了時の温度上昇量は $3^{\circ} \mathrm{C}$ 程度であった。試験体 $\mathrm{S} 6$ の内部鋼板端部温度は, 試験体 S3 における鉛プラグ間中央部の内部 鋼板温度を想定して計測したものであり，図 11 に示した試験体 S3 の FDM 解析結果と同様に, 鉛プラグ中心部の温度上昇量に比べて十 分に小さい值であった。内部鋼板端部温度は加力終了後 20 分経過時 に最大温度となり, その温度上昇量は $12^{\circ} \mathrm{C}$ 程度であった. 試験体 $\mathrm{S} 6$ の鉛プラグ温度は加力終了後 20 分経過時には $33^{\circ} \mathrm{C}$ に低下した．試 験体 S6, S3 の加力サイクル当たりのエネルギー吸収量を比較して図 15 に示寸. 加力サイクル当たりのエネルギー吸収量は加力開始から加 力終了までの全サイクルにおいて両者でほぼ同じ変化を示した.
S3

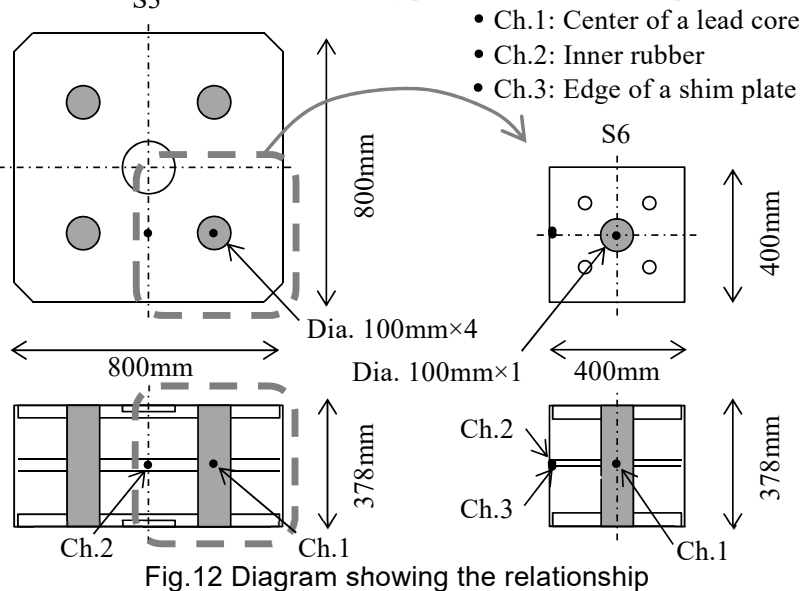

between the specimens S6 and S3.

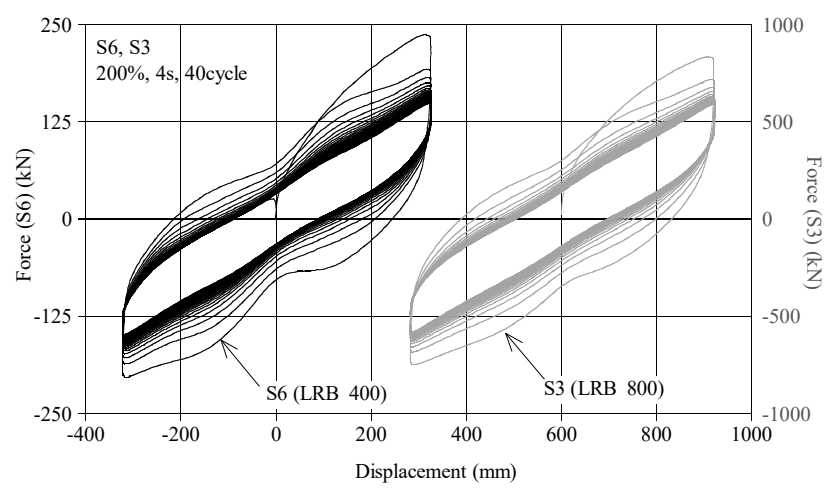

Fig.13 Comparison of experimental results of specimens S6 and S3 in force-displacement relationship.

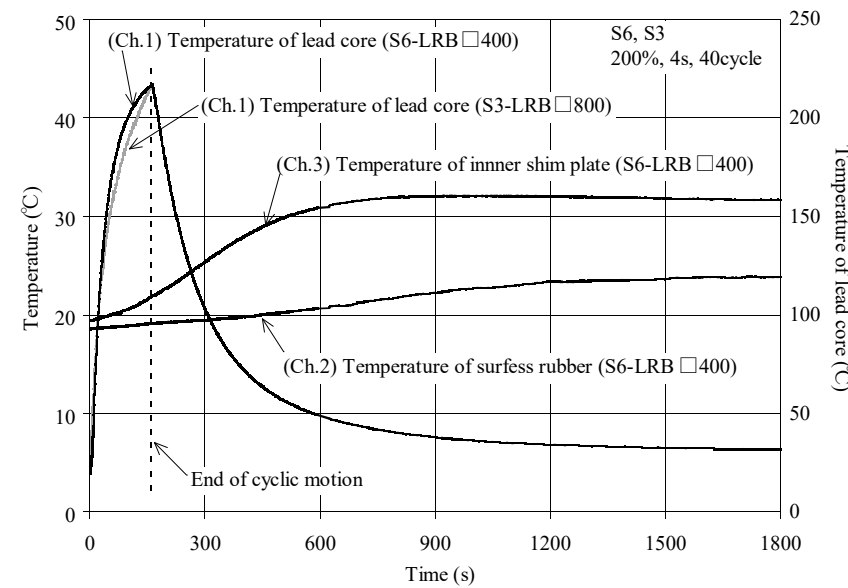

Fig.14 Comparison of experimental results of specimens S6 and S3 in temperature change inside the specimens.

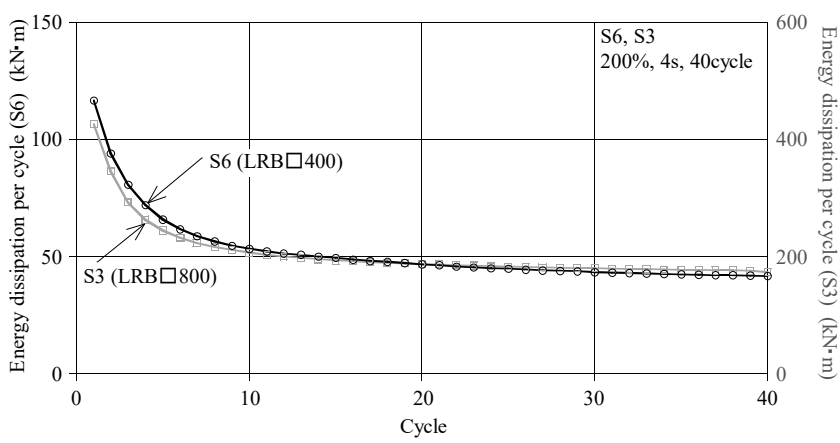

Fig. 15 Comparison of experimental results of specimens S6 and S3 in dissipated energy per cycle. 
鈶プラグ中心温度，および分割を考慮した水平力-水平変位関係， 加力サイクル当たりのエネルギー吸収量の変化が試験体 S6 と S3 と でほぼ一致し，また，鉛プラグ間中央部の温度上昇量が鉛プラグの温 度上昇量に比べて十分に小さいことから，鉛プラグ間の熱的相互作 用はほとんど生じていないことを確認した。

以上から，本研究で検討した範囲では，マルチプラグ LRBにおい てもシングルプラグ LRB と同じ熱伝導方程式を用いた CFS 解法が 適用可能と判断できる. 寸なわち，CFS 解法におけるマルチプラグ LRB の熱伝導解析は，図 12 に示した試験体 S3 と試験体 S6 の関係 のように, 高さ方向は同じとし, 平面を鉛プラグ本数で分割した形状 のモデルに対して実施すれば良いこととなる．鉛プラグ間距離によ る影響については付録に示す。

\section{3 マルチプラグ LRB への二次元 FDM 熱解析モデルの適用}

鈆プラグ間の熱的相互作用がほとんど生じていないことから，マ ルチプラグ LRB を鉛プラグ本数で分割し，さらに等価な丸型シング ルプラグ LRB に置換することにより，マルチプラグ LRB の繰り返 し加力によるエネルギー吸収性能の変化を二次元 FDM 熱解析モデ ルを用いて表現することの検討を行う．図 12 に示した，試験体 S3 を分割した試験体 S6 に対して，さらに図 16 に示すように鉛プラグ せん断面積，ゴムせん断面積が等価になるように丸型シングルプラ グ LRB（モデル R6）に置換する.

せん断ひずみ $200 \%$, 周期 $4 \mathrm{~s} ， 40$ サイクル繰り返し加力における, 試験体 S3 に対して実施した三次元 FDM 熱解析モデルによる解析結 果と，モデル R6 に対して実施した二次元 FDM 熱解析モデルによる 解析結果を比較して図 17 に示寸. 水平力-水平変位関係の履歴形状, 加力サイクルごとのエネルギー吸収量の変化, 鉛プラグ中心温度 (Ch.1)の時刻歴推移は両者でほぼ一致した。また，試験体 S3 の鉛プラ グ間中心位置に相当する，モデル R6 の中心から $200 \mathrm{~mm}$ の位置にお ける内部ゴム(Ch.2), 内部鋼板(Ch.3), 連結鋼板(Ch.4)の温度は, 試験 体 S3 の鉛プラグ間中心位置のそれぞれの温度とほぼ一致した。この ことから, モデル R6 において, 試験体 S3 の鉛プラグ間中心位置に相 当する試験体内部温度の上昇量が鉛プラグ中心温度の上昇量に対して 十分に小さいことを確認することで, 試験体 S3 の解析を行わなくて もモデル R6 の解析から鉛プラグ間の熱的相互作用がほとんど生じな いことを確認できる.

以上から，マルチプラグ LRB の熱力学連成挙動解析は本来なら三 次元熱伝導解析モデルを用いる必要があるが，等価なシングルプラ グ LRB に置換することにより二次元モデルが適用可能となり，より 簡便に熱力学連成挙動解析を行うことが可能となる。

\section{6. 実大マルチプラグ LRB に対する CFS 解法の適用性の検証}

本章では，マルチプラグ LRB に対して CFS 解法を適用し，実験 結果, および三次元モデルによる FDM 解法の結果と比較することに より，マルチプラグ LRB に対する CFS 解法の適用性を検証する.

\subsection{CFS 解法と FDM 解法による解析結果の比較}

試験体 S3 に対して実施した，せん断ひずみ $200 \%$ ，周期 $4 \mathrm{~s} ， 40$ サ イクルの動的繰り返し実験について, CFS 解法, FDM 解法による解 析結果を実験結果と比較して図 18, 19 に示す. マルチプラグ LRB に おける CFS 解法では, 図 12 に示したように, 試験体の 4 分割モデル に対して解析を実施し, 解析から得られた水平力を 4 倍することで解
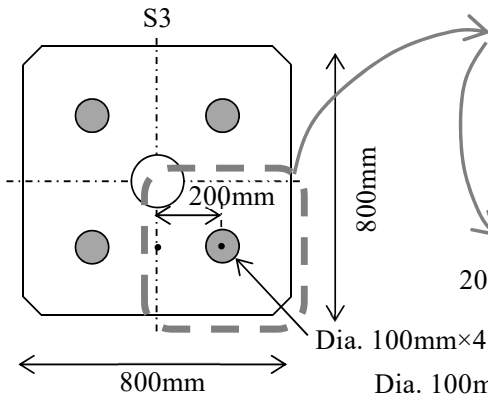

$$
\begin{aligned}
& \mathrm{S} 6 \\
& \mathrm{R} 6
\end{aligned}
$$

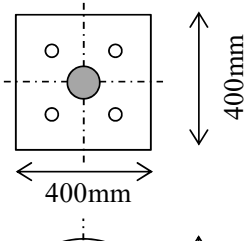

$200 \mathrm{~m}$
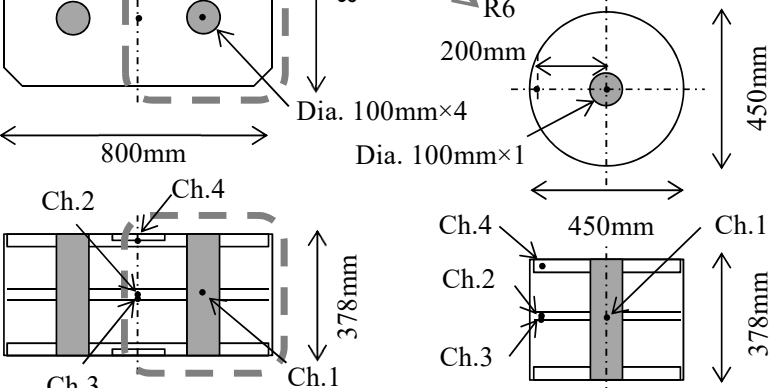

Ch. 3

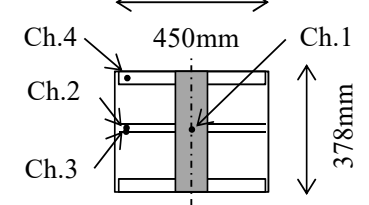

Ch.3

The temperature confirmation locations by the analysis.
Ch.1: Lead core, Ch.2: Rubber, Ch.3: Shim plate, Ch.4: End plate

Fig. 16 Diagram showing the relationship between the specimen S3, S6 and model R6.
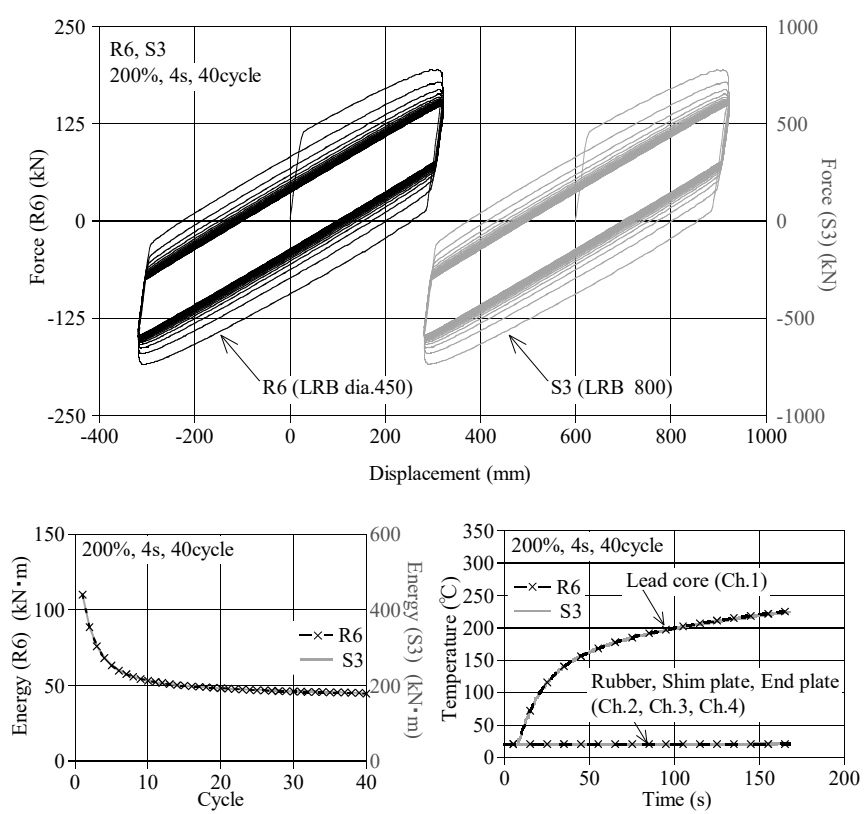

Fig.17 Comparison of analysis results of R6 and S3.
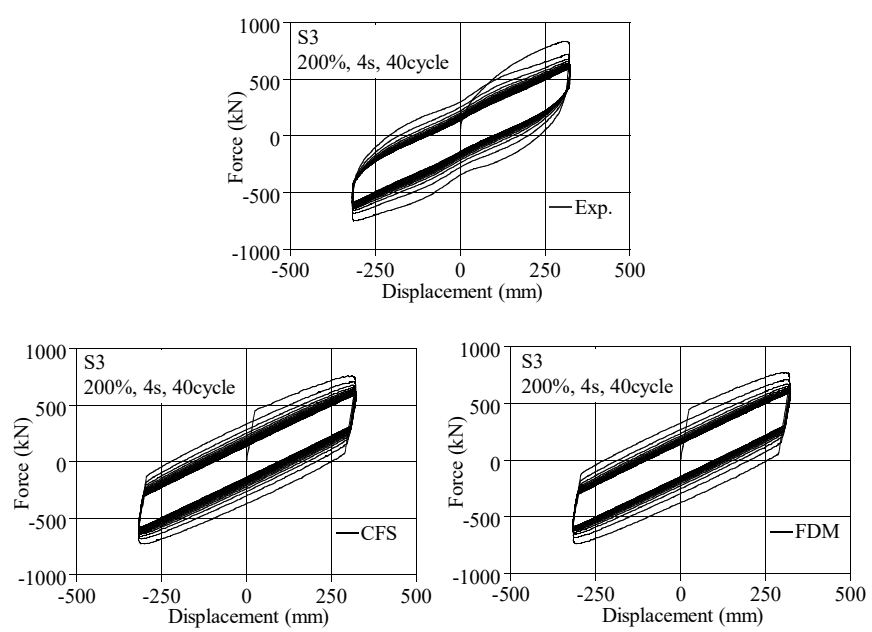

Fig.18 Comparisons of CFS analysis and FDM analysis to experimental results of test specimen S3. 

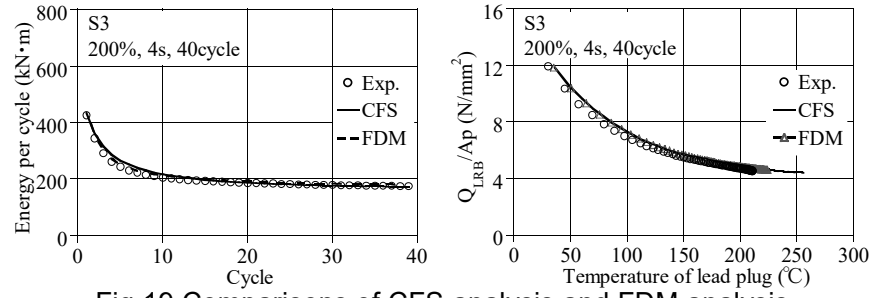

Fig.19 Comparisons of CFS analysis and FDM analysis to experimental results of test specimen S3.

析結果を得ている. 水平力-水平変位関係は CFS 解法と FDM 解法と でほぼ一致し，実験結果とほぼ同じ履歴形状を示した。加力サイクル ごとのエネルギー吸収量の変化は，両解法ともに実験結果とよく整合 しており, 加力初期に低下が大きく, 後半では低下しにくくなる傾向 をよく表現できている．CFS 解法，FDM 解法ともに鉛プラグ中心温 度の最大到達温度が実験結果よりも高くなっているが，LRB 降伏応力 度と鉛プラグ中心温度の関係については実験結果とよく整合している.

\section{2 鉛プラグ径の異なる場合の CFS 解法の適用性}

せん断ひずみ $200 \%$, 周期 4s の動的繰り返し実験について, ゴム 層総厚さが同じ $(160 \mathrm{~mm}) て ゙ ，$ 鉛プラグ径を変化させた試験体 $\mathrm{S} 1 ， \mathrm{~S} 5$ の解析結果を実験結果と比較して図 20 に示す. 水平力-水平变位関 係の解析結果は, 実験結果とほぼ同じ履歴形状を示した. 実験から得 られた加力サイクルごとのエネルギー吸収量は，鉛プラグ径が太く なると加力初期はエネルギー吸収量が大きくなるが，繰り返し加力 による低下量も大きくなっている．解析結果は実験結果とよく整合 しており，鉛プラグ径が異なる場合においても繰り返し加力に伴う エネルギー吸収量の変化をよく表現できている.
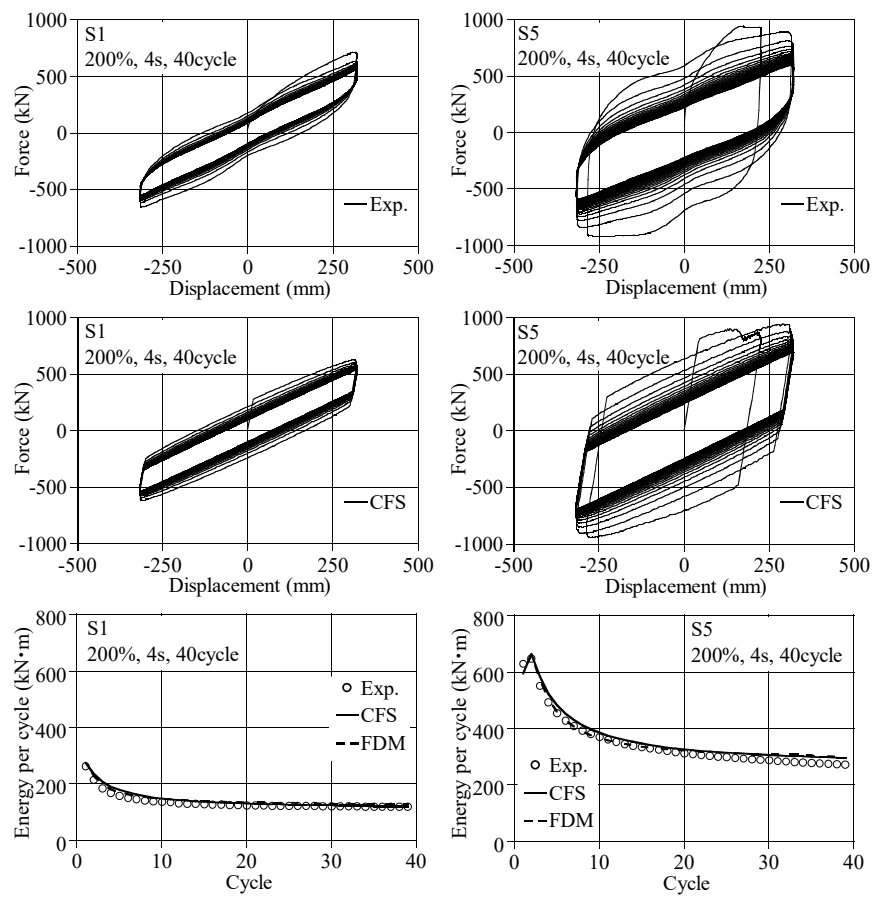

Fig.20 Comparisons of analysis results with experimental results in cases when the lead core diameter is small or large.

\section{3 ゴム層総厚さ異なる場合の CFS 解法の適用性}

ゴム層総厚さが $200 \mathrm{~mm}$ の試験体 $\mathrm{S} 4$ に対して実施したせん断ひず み $200 \%$, 周期 4s の動的繰り返し実験について, 解析結果を実験結
果と比較して図 21 に示す. ゴム層総厚さが厚くなると, 変形量が大 きくなるため加力サイクル当たりのエネルギー吸収量は S3 試験体 の結果と比べて大きくなっている．解析結果はゴム層総厚さが異な る場合においても，実験結果をよく表現できている.
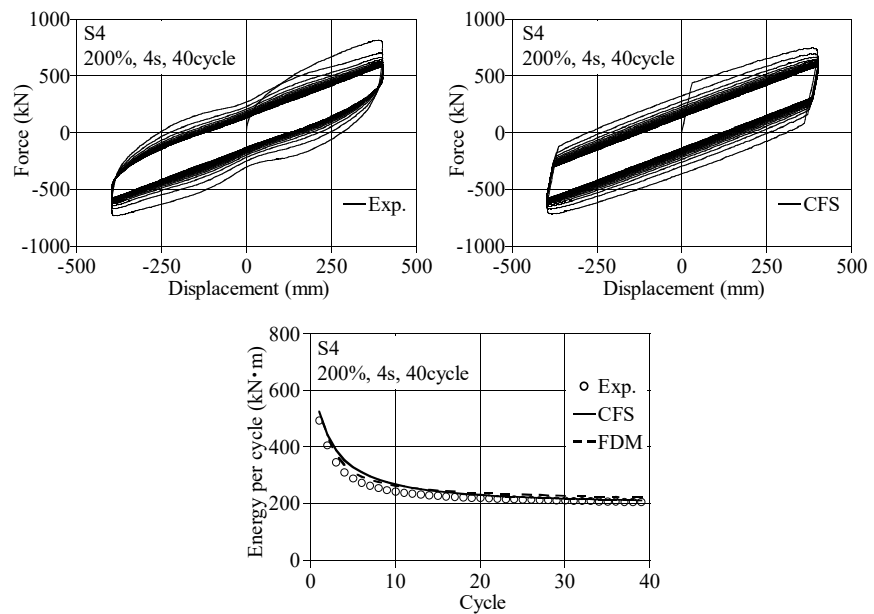

Fig.21 Comparisons of analysis results with experimental results in cases when the total rubber layer thickness is large.

\section{4 加力周期が異なる場合の CFS 解法の適用性}

試験体 S3 に対して実施したせん断ひずみ $200 \%$ ，加力周期 $125 \mathrm{~s}$, および $2 \mathrm{~s}$ の解析結果を実験結果と比較して図 22 に示寸. 周期 $4 \mathrm{~s}$ の 結果は図 18,19 に示している. 加力周期が長い場合, 水平力-水平変 位関係は加力サイクルが増えても大きな変化は見られず，エネルギ 一吸収量の変化も小さい，加力周期が短くなると加力初期のエネル ギー吸収量が大きくなり，加力サイクルが増えるに従いエネルギー 吸収量は低下している. 解析結果は, CFS 解法, FDM 解法ともに, 実験で確認された上記の現象をよく表現できている。
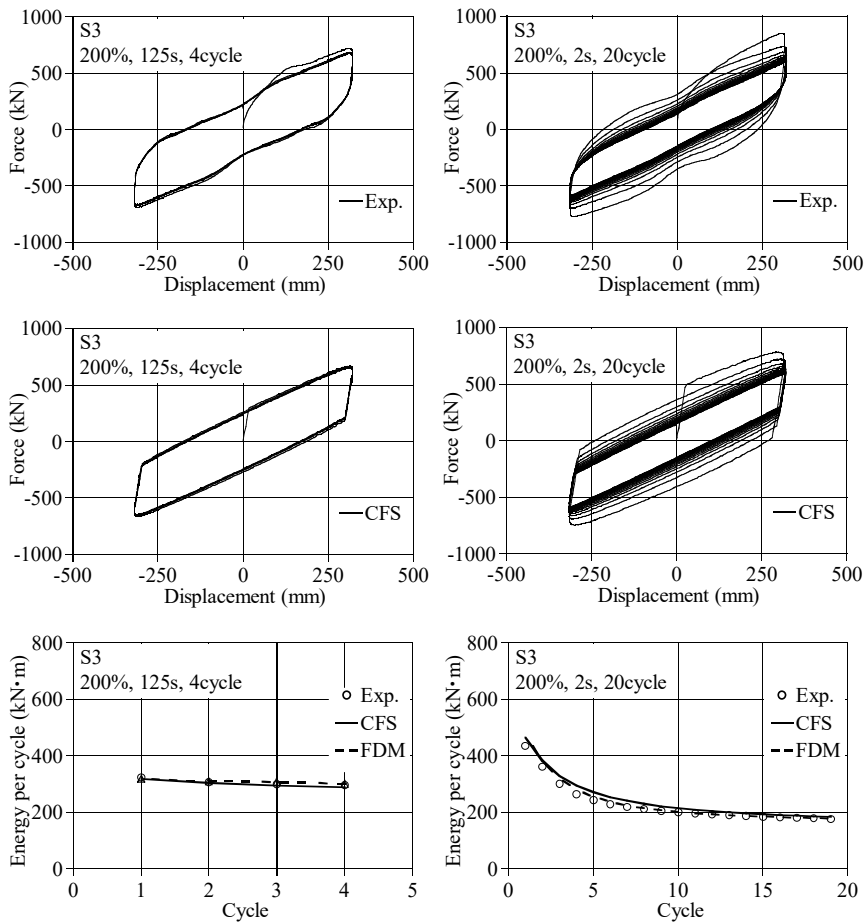

Fig.22 Comparison of analysis results with experimental results in cases when the vibration period is long or short. 


\section{5 せん断ひずみ量が異なる場合の CFS 解法の適用性}

試験体 S3 に対して実施した, せん断ひずみ $100 \%$, 加力周期 $66.7 \mathrm{~s}$, $8 \mathrm{~s} ， 4 \mathrm{~s} ， 2 \mathrm{~s}$ の解析結果を実験結果と比較して図 23 に示寸. せん断ひ ずみ $100 \%$ の実験結果は，200\%の結果に比べると，加力サイクル当た りのエネルギー吸収量が小さくなる. せん断ひずみ $100 \%$ たいても, $200 \%$ の結果と同様に加力周期が長いとエネルギー吸収量はほとんど 変化せず，加力周期が短くなると加力初期のエネルギー吸収量が大き くなり, 加力サイクルが増えるに従いエネルギー吸収量は低下してい る. 解析結果は, せん断ひずみ $100 \%$ 実験結果に対しても， CFS 解 法, FDM 解法ともに, 実験で確認された上記の現象をよく表現できて いる.

\section{7. 結論}

LRB の鉛プラグの分散配置がエネルギー吸収性能に与える効果に ついて把握するため，実大サイズのマルチプラグ LRB，シングルプ ラグ LRB に対して動的繰り返し加力実験を実施した。また, 分割試 験体に対する実験，および解析検討から，マルチプラグ LRBへの熱 力学連成挙動解析の適用方法について検討し, 以下の結論を得た.

[1] 動的繰り返し加力実験を行うと, 鉛プラグ温度は鉛プラグ径が太 いほど温度上昇量は増大し，その結果エネルギー吸収性能は低下し やすくなる. マルチプラグ LRB はシングルプラグ LRB に対して鋁 プラグのせん断抵抗面積を変えずに鉛プラグ径を小さくできるため, 繰り返し加力に伴うエネルギー吸収性能の低下を抑制する効果があ る. 本論におけるせん断ひずみ $200 \%$ ，周期 $4 \mathrm{~s} ， 40$ サイクルの動的 繰り返し実験では, 鉛プラグ中心温度の上昇量は $70^{\circ} \mathrm{C}$ 程度抑制され, エネルギー吸収量の低下率は $17 \%$ 程度の改善が見られた。

[2] 三次元モデルを用いた FDM 解法(差分法)による, 著者らの提案す るLRB 降伏荷重評価式を組み込んだ熱力学連成挙動解析はマルチプ ラグ LRBの実験結果を精度よく表現できる.
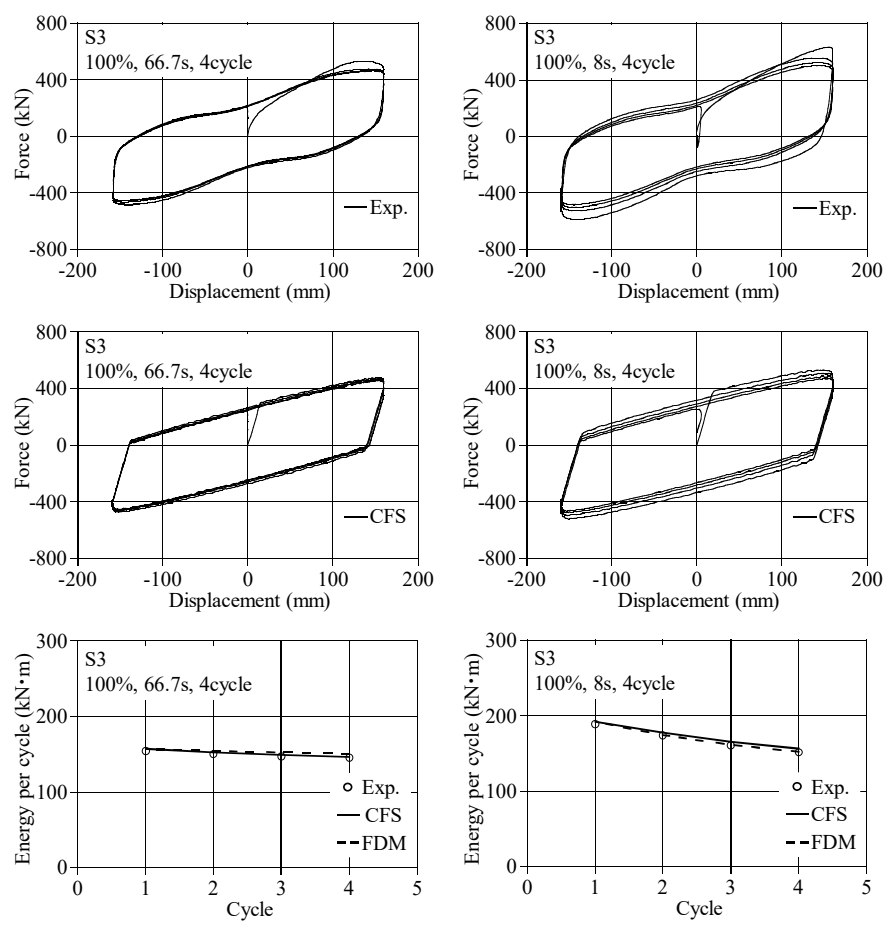

[3] マルチプラグ LRB と分割試験体の実験，および三次元モデルを 用いた FDM 解法による解析結果から, 隣接寸る鉛プラグ間の熱的 相互作用が十分に小さいことを確認した．その結果，マルチプラグ LRB に対して CFS 解法(定熱流束解析手法)が適用可能である.

[4] CFS 解法による, 著者らの提案する LRB 降伏荷重評価式を組み 込んだ熱力学連成挙動解析はマルチプラグ LRB の実験結果を精度 よく表現できる.

[5] マルチプラグ LRB に対する二次元モデルを用いた FDM 解法に よる熱力学連成挙動解析手法について示した. マルチプラグ LRBを 等価丸型モデルに置換して解析を行うことにより, 二次元モデルに よる解析においても，三次元モデルを用いた場合と同等の精度の結 果を得られる.

[6] マルチプラグ LRB において, 鉛プラグ間の熱的相互作用が十分に 小さく, 分割試験体と元の試験体の結果がほぼ一致することを実験的 に確認した．このことから，試験機能力により動的繰り返し加力が困 難な大きさの試験体に対しては, 試験体を分割して実験を行うことに より，エネルギー吸収性能の変化を実験的に確認できる.

[7] ゴム層総厚さを変えた試験体に対する繰り返し加力実験の結果, 加力サイクルごとの降伏応力度に違いは見られなかった. FDM 解法, CFS 解法による解析結果においても顕著な違いは見られなかったこ とから, 積層ゴム外形とゴム層総厚さの比が $4 \sim 5.6$ 程度の, 今回実 験で確認した範囲であればエネルギー吸収性能に顕著な違いはない

以上より, 鉛プラグの分散配置は繰り返し加力を受ける LRB のエ ネルギー吸収性能の低下を抑制する効果があり, 解析的に精度よく 表現できることを示した。

角型マルチプラグ LRB は本来なら三次元熱伝導解析モデルによ る熱・力学連成解析が必要であり, 解析時間も長くなる。しかし, 本 研究における一連の検討により，1/4 に分割したモデルによる CFS 解法が適用可能であり, さらに等価な丸型シングルプラグに置換し
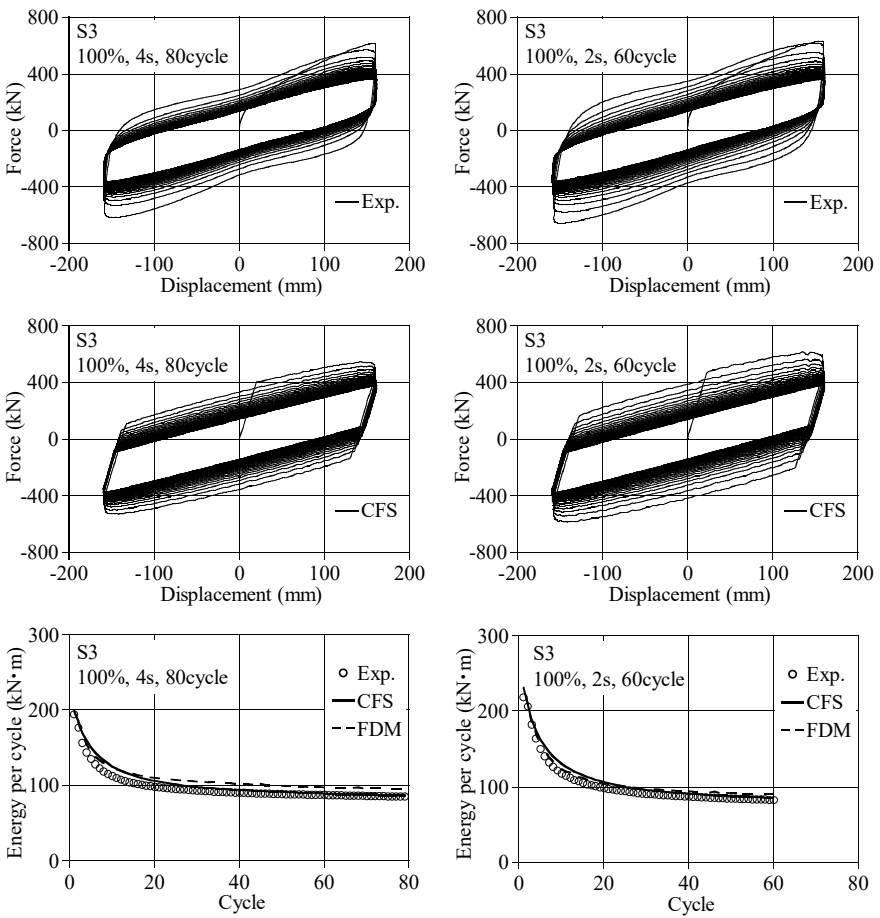

Fig.23 Comparison of analysis results with experimental results in cases when the vibration period is long or short at $100 \%$ shear strain test. 
た二次元 FDM 熱解析モデルが適用できることが明らかになった.こ れにより, 繰り返し加力を受ける角型マルチプラグ LRB の熱・カ学 連成解析の大幅な効率化, 簡略化が可能となる.

\section{参考文献}

1) Kondo, A. et al.: Heat-Mechanics Interaction Behavior of Laminated Rubber Bearings under Large and Cyclic Lateral Deformation (Part 10: Proposal of Relationship between Temperature and Shear Stress of Lead Plug), Summaries of Technical Papers of Annual Meeting, Architectural Institute of Japan, Structures-II, pp.399-400, 2008.9 (in Japanese)

近藤明洋, 竹中康雄, 高岡栄治, 引田真規子, 北村春幸, 宮崎充 : 大振幅繰 返し変形を受ける積層ゴム支承の熱・力学的連成挙動に関する研究 (その 10），日本建築学会大会学術講演梗概集, B-II, pp.399-400, 2008.9

2) Ioannis V. Kalpakidis and Michael C. Constantinou: Effects of Heating on the Behavior of Lead-Rubber Bearings. I: Theory, JOURNAL OF STRUCTURAL ENGINEERING, pp1440-1449, 2009.12

3) Kitamura, Y. et al.: A Hysteresis Model for Lead Rubber Bearings including Multi-Cyclic Characteristics Part 2: Hysteresis Model, Summaries of Technical Papers of Annual Meeting, Architectural Institute of Japan, Structures-II, pp.387-388, 2012.9 (in Japanese) 北村佳久, 山本祥江, 西村拓也, 福喜多輝 : 多数回繰返し変形による特性 変動を考慮した鉛プラグ入り積層ゴムの復元力モデルの構築 その $2:$ 繰 返しによる特性変動を考慮した復元力モデル, 日本建築学会大会学術講 演梗概集, B-II, pp.387-388, 2012.9

4) Muramatsu, A. et al.: Cyclic Loading Experiment on Lead Rubber Bearing with Large Diameter Lead Plug, AIJ Journal of Technology and Design, Vol.22, No.52, pp.987-992, 2016.10 (in Japanese)

村松晃次, 日比野浩, 猪野晋, 栗栖藍子, 小室務, 仲村崇仁, 和氣知貴 : 太 径鉛プラグ入り積層ゴム支承の繰り返し載荷試験, 日本建築学会技術報 告集, 第 22 巻 第 52 号, pp.987-992, 2016.10

5) Wake T. et al.: A New Evaluation Method for Yielding Force of Lead Rubber Bearings under Cyclic Loading, Journal of Structural and Construction Engineering (Transactions of AIJ), Vol.83, No.750, pp.1105-1115, 2018.8 (in Japanese)

和氣知貴, 菊地優, 石井建, 黒嶋洋平, 仲村崇仁: 繰り返し加力を受ける鉛 プラグ入り積層ゴム支承の降伏荷重評価法に関する研究，日本建築学会 構造系論文集 第 83 巻 第 750 号, pp.1105-1115, 2018.8

6) Wake T. et al.: Heat-Mechanics Interaction Analysis of Lead-Rubber Bearings using the Constant Flux Solution, Summaries of Technical Papers of Annual Meeting, Architectural Institute of Japan, Structures-II, pp.1015-1016, 2018.9 (in Japanese)

和氣知貴, 菊地優, 石井建 : 定熱流束解析手法を用いた鉛プラグ入り積層 ゴム支承の熱力学連成挙動解析, 日本建築学会大会学術講演梗概集, B-II, pp.1015-1016, 2018.9

7) Osamu, K. et al.: Behavior of real scale Lead Rubber Bearing shaking test under the real scale earthquake response, 13th Asia Pacific Vibration Conference 22-25, 2009.11

8) Kondo, A. et al.: Study on Multi-cyclic Modeling of Devices and Response Evaluation for Seismic Isolation against Long Period Earthquake Motions Part1: Lead-Plugged Rubber Bearing, Summaries of Technical Papers of Annual Meeting, Architectural Institute of Japan, Structures-II, pp.375-376, 2012.9(in Japanese)

近藤明洋, 竹中康雄，高山峯夫，古橋剛，菊地優，飯場正紀 : 長周期地震動 に対する免震部材のモデル化と免震建築物の応答評価その 1 : 鉛プラグ入 り積層ゴムの地震応答解析, 日本建築学会大会学術講演梗概集, B-II, pp.375-376, 2012.9

\section{付録 鉛プラグ間の熱的相互作用と鉛プラグ間距離に関する考察}

マルチプラグ LRB における鉛プラグ間の熱的相互作用に与える鉛 プラグ表面間距離の影響を確認するため, 鉛プラグ間距離を意図的に 短くした試験体 S1’を製作し，せん断ひずみ $200 \%$ ，周期 $4 \mathrm{~s}$ の繰り返 し加力実験を実施した。試験体 $\mathrm{S} 1$ ’は外形，鉛プラグ径は試験体 $\mathrm{S} 1$ と
同じだが, 鉛プラグ間距離を試験体 $\mathrm{S} 1$ の半分の $200 \mathrm{~mm}$ としており， 鈶プラグ表面間距離は $120 \mathrm{~mm}$ である. 試験体 $\mathrm{S} 1^{\prime}$ の概要と水平力-水 平変位関係の実験結果を図 a 1 に示し, エネルギ一吸収量, 内部温度の 変化を試験体 $\mathrm{S} 1$ と比較して図 $\mathrm{a} 2$ に示す. 水平力-水平変位関係の実 験結果は試験体 S1’と S1（図 20）とでほぼ一致している. 試験体 S1' の鉛プラグ間中央ゴム温度は試験体 $\mathrm{S} 1$ に比べて $20^{\circ} \mathrm{C}$ 程度上昇が大 きい結果となったが，加力サイクルごとのエネルギー吸収量にはほと んど影響が見られない. 次に，市場に流通している外形 $800 \mathrm{~mm}$ のマ ルチプラグ LRBにおいて鉛径が最も太い試験体 S3 に対する FDM 解 析から得られた, 高さ方向中央における鉛プラグ間温度分布を加力サ イクルごとに図 a 3 に示す. 加力終了時における温度上昇は鉛プラグ 中心部で大きく, 半径方向に小さくなり, 鉛プラグ表面から $60 \mathrm{~mm} の$ 位置では約 $13^{\circ} \mathrm{C}, 100 \mathrm{~mm}$ の位置では約 $2^{\circ} \mathrm{C}$, 鈶プラグ間中央の $150 \mathrm{~mm}$ の位置ではほとんど生じなかった。市場に流通しているマル チプラグ LRB のうち，鈶プラグ表面間距離は最も短い場合でも $245 \mathrm{~mm}$ あり，実用上鉛プラグ間距離の影響を考慮する必要は無い.

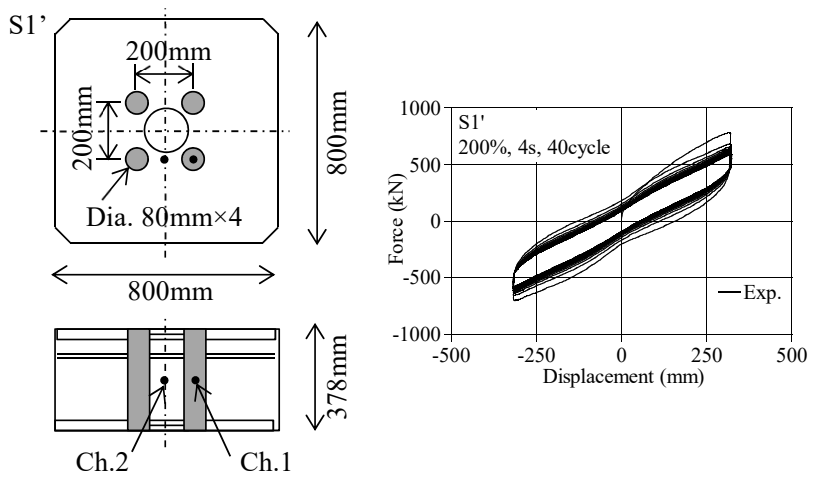

Fig.a1 A test specimen (S1') to confirm the influence of gathered lead-core configurations and experimental result.
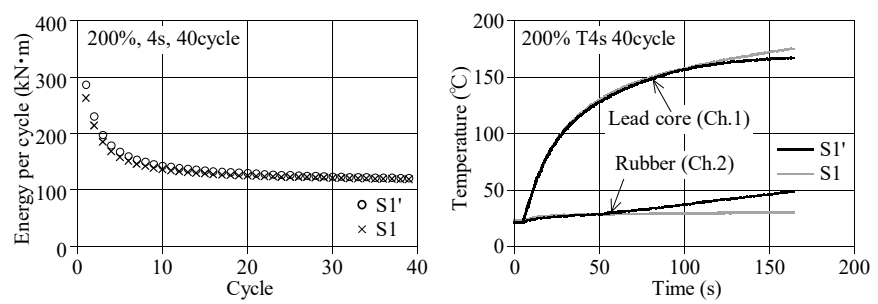

Fig.a2 Comparisons of the experimental results of S1' and S1.

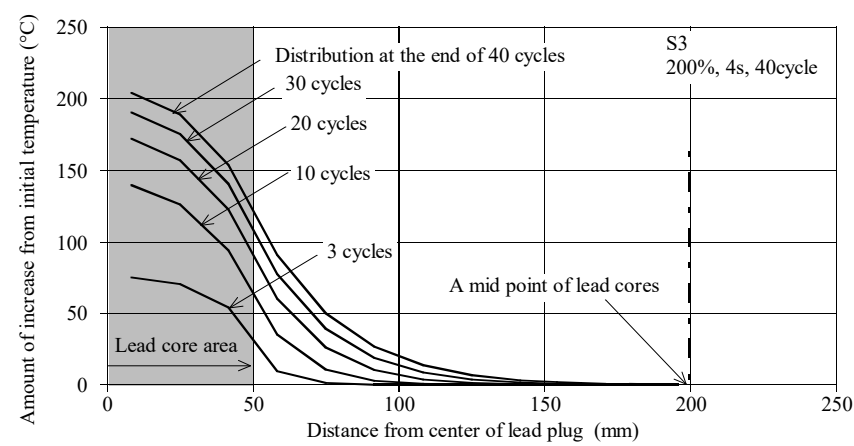

Fig.a3 Change of temperature distribution between lead cores with each cycle obtained from FDM analysis. 


\title{
IMPROVED THERMO-DYNAMIC BEHAVIOR OF LEAD-RUBBER ISOLATION BEARINGS DUE TO DISTRIBUTED LEAD-CORE CONFIGURATIONS
}

\author{
Tomotaka WAKE ${ }^{* 1}$, Ken ISHII*2 and Masaru KIKUCHI*3 \\ *1 Development Dept., Damping and Isolation Division, Oiles Corporation, M.Eng. \\ ${ }^{* 2}$ Assist. Prof., Faculty of Engineering, Hokkaido University, Dr.Eng. \\ ${ }^{*}$ Prof., Faculty of Engineering, Hokkaido University, Dr.Eng.
}

It has been shown that if a lead-rubber isolation bearing (LRB) repeatedly undergoes large deformation due to long periodic characteristics and a long-period earthquake accompanied by strong ground vibration, the lead core generates heat and the energy absorption performance of the LRB decreases.

There are two types of LRB: a single-core LRB with one lead core and a multi-core LRB with two or more lead cores distributed. The multi-core LRB can increases the surface area of the lead core without changing the total shear area of the lead core as compared with the single-core LRB. In other words, the heat dissipation characteristics of the lead core can be improved without changing its basic shear resistance.

To clarify the effectiveness of the distributed lead-core configurations of LRB on energy absorption during an earthquake, dynamic and cyclic loading experiments were conducted on actual-size multi-core LRB and single-core LRB of various shapes (Fig. 1).

The results of experiments showed that the energy absorption performance tends to decrease with larger diameter of the lead core, and that the multi-core LRB effectively restrains such decline of performance (Figs. 2, 3). It was also confirmed that the total thickness of the rubber layer has little influence on the energy absorption (Fig. 4, 5).

To conduct a heat-mechanics interaction analysis of the multi-core LRB, it is usually necessary to use a threedimensional model, but this method requires much effort for creating a model and the computation time is long. Therefore, in this research, we propose a simple analysis method for multi-core LRB and show that the thermal interaction between lead cores is small. We confirmed the thermal interaction between the lead cores of the multicore LRB by cyclic loading tests and also conducted an experiment on a specimen divided by the number of lead cores. (Fig. 12).

As a result, the rise in temperature inside the specimen located at the center between the lead cores of the multicore LRB was slight, and the results of the experiments on the divided test specimens matched those of the specimen before being divided (Fig. 13 to 15). Since thermal interaction between lead cores hardly occurs in the multi-core LRB, it is considered that the Constant Flux Solution (CFS), which calculates by simplifying the heat dissipation path from the lead core, can be applied to heat-mechanics interaction analysis of the multi-core LRB. Furthermore, by replacing the divided specimen with an equivalent round model, the two-dimensional Finite Difference Method (FDM) model can be applied to the multi-core LRB (Figs. 16, 17).

From the above, CFS analysis and FDM analysis using the evaluation formulae (Equations (1) - (3)) proposed by the authors for the yield stress of the lead core were performed on the multi-core LRB. As a result, we confirmed that both analytical methods accurately predict the experimental results of the multi-core LRB (Figs. 18 to 23).

Based on the above, we clarified that the reduction of energy absorption due to repeated deformation of the LRB for a long time can be improved by the distributed lead-core configurations. 